\title{
Anti-nociceptive, anti-inflammatory and antipyretic activities of the ethanol root bark extract of Salacia lehmbachii in rats and mice
}

\author{
Godwin C. Akuodor ${ }^{1 *}$, Sylvester C. Ohadoma ${ }^{2}$, Casimir C. Ofor ${ }^{3}$, Anthony U. Megwas ${ }^{4}$, \\ Leo C. Chukwu ${ }^{5}$, Mansur A. Ramalan ${ }^{6}$, Dorcas O. Okoroafor ${ }^{7}$, Kingsley C. Chilaka ${ }^{1}$
}

\author{
${ }^{1}$ Department of Pharmacology and Therapeutics, Faculty of Medicine, College of Health Sciences, Nnamdi Azikiwe \\ University, Nnewi Campus, Nigeria \\ ${ }^{2}$ Department of Pharmacology, College of Medical Sciences, University of Calabar, Nigeria \\ ${ }^{3}$ Department of Pharmacology and Therapeutics, Faculty of Medicine, Ebonyi State University, Abakaliki, Nigeria \\ ${ }^{4}$ Department of Optometry, School of Health Technology, Federal University of Technology, Owerri, Nigeria \\ ${ }^{5}$ College of Medicine, Chukwuemeka Odumegwu Ojukwu University, Amaku, Awka, Nigeria \\ ${ }^{6}$ Department of Pharmacology and Therapeutics, College of Health Sciences, Bayero University, Kano \\ 7Department of Biomedical Technology, School of Science Laboratory Technology, University of Port Harcourt, \\ Nigeria
}

Received: 21 February 2021

Accepted: 31 April 2021

*Correspondence:

Dr. Godwin C. Akuodor,

Email: goddyakuodor@yahoo.com

Copyright: (C) the author(s), publisher and licensee Medip Academy. This is an open-access article distributed under the terms of the Creative Commons Attribution Non-Commercial License, which permits unrestricted non-commercial use, distribution, and reproduction in any medium, provided the original work is properly cited.

\begin{abstract}
Background: The decoction of the roots of Salacia lehmbachi is used in traditional medicine for the treatment of different diseases such as malaria pains diabetes and microbial infections.

Methods: Phytochemical screening and oral acute toxicity tests were carried out on the ethanol root extract of the plant. Anti-nocicetive activity using acetic acid induced writhing and tail immersion method in mice, anti-inflammatory activity using carrageenan induced paw oedema in rats and xylene induced ear oedema test in mice and antipyretic activity using Brewer's yeast and D-amphetamine induced pyrexia in rats were determined at $50 \mathrm{mg} / \mathrm{kg}, 100 \mathrm{mg} / \mathrm{kg}$ and $200 \mathrm{mg} / \mathrm{kg}$ doses of the root extract.

Results: The ethanol root extract contain alkaloids, saponins, tannins, flavonoids, terpenoids, steroids and cardiac glycosides. The oral acute toxicity tests was found to be greater than $5000 \mathrm{mg} / \mathrm{kg}$. The root extract and the standard drug (Aspirin) significantly $(\mathrm{p}<0.05$ and $\mathrm{p}<0.01)$ decreased the number of writhes caused by acetic acid. The extract and morphine significantly $(\mathrm{p}<0.05$ and $\mathrm{p}<0.01)$ prolonged reaction time in tail immersion model. The extract produced significant $(\mathrm{p}<0.05$ and $\mathrm{p}<0.01)$ dose dependent inhibition of oedema which was comparable to aspirin in carrageenan induced paw oedema model. The root extract also demonstrated significant $(p<0.05$ and $p<0.01)$ effect in xylene induced mouse ear oedema test compared to dexamethasone. The extract significantly decreased high temperature in both Brewer's yeast and d-amphetamine induced pyrexia.

Conclusions: Findings show that S. lehmbachii may provide a good source of plant compounds with analgesic, antiinflammatory and antipyretic activities.
\end{abstract}

Keywords: Salacia lehmbachii, Analgesic, Anti-inflamatory, Antipyretic, Rats, Mice

\section{INTRODUCTION}

Inflammation which is a response to infection or injury is characterized by pain, heat, swelling, redness and disrupted physiological functions. Chemical mediators released from injured tissue and migrating cells can induce inflammation. ${ }^{1}$ Non-steroidal anti-inflammatory drugs (NSAIDs), aspirin and opionates generally used for the 
management of inflammatory conditions have not been successful in all cases as a result of adverse effects such as liver damage and ulcers. ${ }^{2,3}$ The strategy should therefore be the search for clinically new and useful antiinflammatory agents which have negligible or no side effects. It has been recorded that agents derived from natural products are able to affect a wide range of pathways involved in the inflammatory response, including different inflammatory mediators like cytokines, arachidonic acid metabolites, excitatory amino acids, peptides and others. ${ }^{1}$ Fever is due to the elevation of core body temperature above normal. ${ }^{4}$ Fever may be due to infection, inflammation, or any tissue damage cdand disease state. It arises as a secondary impact of infection, malignancy or other diseased states. ${ }^{5}$

Salacia lehmbachii Loes which belongs to the family Celastraceae is used in traditional medicine for different ailments. This plant is native to Nigeria, Cameroon, Liberia, Senegal and Tanzania. Different studies showed the antidiarrhoeal, antimicrobial and anti-ulcer effects of both the leaves and the root of the plant. ${ }^{6,7}$ More so, anticholinergic activity, anti-infertility and anti-hemorroid effects, as well as antioxidant activity were studied..$^{8-11}$ The objective of this study was to evaluate the anti-nociceptive, anti-inflammatory and antipyretic activities of ethanol extract of $S$. lehmbachii root bark in rats and mice.

\section{METHODS}

\section{Plant collection}

The roots of Salacia lehmbachii were harvested from a farm land at Ukanafun local government area, Akwa Ibom State, Nigeria. The plant was identified and authenticated in the herbarium of the department of botany, University of Calabar. The specimen with registration number 688 was deposited at botany department herbarium, University of Calabar.

The roots were collected air-dried for fourteen days and the size was reduced with mortar and pestle. The powdered material was then subjected to extraction using soxhlet extractor for 48 hours, and the filtrate was evaporated on water bath at reduced temperature of $45^{\circ} \mathrm{C}$ to obtain a brown solid residue.

\section{Experimental animals}

Male and female wistar rats and mice weighing 150-180 g and 20-25 g respectively were obtained from the animal house of the department of pharmacology and therapeutics, University of Calabar. The animals were allowed free access to standard feed and water ad libitum. They were kept six each in clean separate cages with saw dust as bedding, which was replaced every two days.

The study was conducted according to ethical guidelines on laboratory animal use and care which is incompliance with University of Calabar Research Policy
(ERN/025PA30617) and the authors of this manuscript observed ethical issues. The National Institute of Health Guide for the care and use of laboratory animals was also adopted for this study. ${ }^{12}$

\section{Acute toxicity test}

Acute toxicity testing of ethanol root bark of S. lehmbachii extract was estimated in both rats and mice using modified method in two phases. ${ }^{13}$ The animals were deprived of food overnight prior to administration of the extract. In phase 1 , three groups of three animals in each cage were used. The root bark extract was orally administered geometrically in increasing doses of $10 \mathrm{mg} / \mathrm{kg}, 100 \mathrm{mg} / \mathrm{kg}$ and $1000 \mathrm{mg} / \mathrm{kg}$ respectively. The animals were then monitored for first 4 hours for signs of toxicity and mortality for 24 hours. When no lethality was observed, phase 2 was introduced. In second phase, three groups of one animal were intragastrically given the extract in geometrically increasing doses of $1600 \mathrm{mg} / \mathrm{kg}$, $2900 \mathrm{mg} / \mathrm{kg}$ and $5000 \mathrm{mg} / \mathrm{kg}$ respectively. The animals were also observed for first 4 hour for physical signs of toxicity and mortality for 24 hours.

\section{Anti-nociceptive test}

\section{Acetic acid induced writhing in mice}

The ethanol root bark extract was assessed for analgesic activity using acetic acid-induced writhing method. ${ }^{14}$ Albino mice (20-25 g) of both sexes randomized into 5 different cages of 6 mice in each cage. Group 1 (drug free) was given normal saline $(20 \mathrm{ml} / \mathrm{kg})$, the extract (50 mg/kg, $100 \mathrm{mg} / \mathrm{kg}$ and $200 \mathrm{mg} / \mathrm{kg}$ ) were administered to group 2-4, respectively. The positive control received $(150 \mathrm{mg} / \mathrm{kg})$ of acetyl salicylic acid (ASA).

After thirty minutes, intraperitoneal injection of acetic acid $(10 \mathrm{ml} / \mathrm{kg}, 0.7 \%)$ was administered to each mouse. They were separately placed in a transparent cage for observation. The writhing movements for each mouse was counted for 30 minutes.

\section{Tail immersion test}

Pain latencies of the extract was measured according to the methods. ${ }^{15,16}$ Albino mice of both sexes grouped into 5 cages with 6 mice per group were assayed. Group 1 was treated with normal saline, groups 2-4 were treated with different doses of the extracts $(50 \mathrm{mg} / \mathrm{kg}, 100 \mathrm{mg} / \mathrm{kg}$ and $200 \mathrm{mg} / \mathrm{kg}$. The last group 5 was treated with morphine (10 $\mathrm{mg} / \mathrm{kg}$ ). Thirty minutes after treatment, each mouse was kept in a restrainer cage with the tail freely hanging inside hot water of $50 \pm 1^{\circ} \mathrm{C}$ temperature.

The results were recorded after tail withdrawal. Readings were taken at 30, 60, 90 and 120 minutes interval. The mice used were initially screened and those that did not attempt to withdraw the tail in 10 seconds were not listed for the study. 


\section{Anti-inflammatory effect}

\section{Carrageenan induced paw oedema test}

The carrageenan-induced paw oedema test as described by was used with slight modification. ${ }^{17}$ Thirty wistar rats grouped into five with six rats in each cage were used for the experiment. Group 1 served as negative control (10 $\mathrm{mL} / \mathrm{kg}$ distilled water), group 2 positive control (150 $\mathrm{mg} / \mathrm{kg}$ aspirin), while groups 3, 4 and 5 were administered $50 \mathrm{mg} / \mathrm{kg}, 100 \mathrm{mg} / \mathrm{kg}$ and $200 \mathrm{mg} / \mathrm{kg}$ of the ethanol root bark extract of $S$. lehmbachii respectively. Acute inflammation was induced $30 \mathrm{~min}$ after treatment by administration of $0.1 \mathrm{~mL}$ of $1 \%$ suspension of carrageenan into the subplantar right hind paw of the rats. Assessment of volume of oedema using plethysmometer was implemented. Reading was first taken before treatment and after 20 min intervals for 2 hours. ${ }^{18}$

\section{Xylene induced ear oedema method}

This method as described by was adopted but with slight modification. ${ }^{19}$ Mice were grouped into 5 with 6 animals in each. The animals were orally treated with the root bar extract in graded doses of $50 \mathrm{mg} / \mathrm{kg}, 100 \mathrm{mg} / \mathrm{kg}$ and $200 \mathrm{mg} / \mathrm{kg}$. The negative control group was treated with $10 \mathrm{ml} / \mathrm{kg}$ of distilled water, while the positive control was treated with $4 \mathrm{mg} / \mathrm{kg}$ of dexamethasone. Oedema was induced in each mouse one hour after treatment with a drop xylene into the inner surface of the right ear. Three hour later, mice were sacrificed and both cut-off to equal size and weighed. The mean difference between the right and left ears were recorded as an indication of inflammation.

\section{Antipyretic activity}

\section{Brewer's yeast induced pyrexia}

The antipyretic activity was evaluated using Brewer's yeast induced pyrexia in rats as described.$^{20}$ Fever was induced by administering $20 \mathrm{ml} / \mathrm{kg}$ of $20 \%$ aqueous suspension of Brewer's yeast in distilled water subcutaneously 24 hours before treatment. Thirty wistar rats of both sexes were divided into five groups, 1 and 2 served as negative control (distilled water $20 \mathrm{ml} / \mathrm{kg}$ ) and positive control (paracetamol $150 \mathrm{mg} / \mathrm{kg}$ ), while groups 3 , 4 , and 5 received $50 \mathrm{mg} / \mathrm{kg}, 100 \mathrm{mg} / \mathrm{kg}$, and $200 \mathrm{mg} / \mathrm{kg}$ of the extract respectively. All drugs were administered orally. Rectal temperatures were taken by the use of digital thermometer (Mediklin, China) before yeast injection, 24 $\mathrm{h}$ after the injection, and at 1,2, 3, 4 and 5 hours after drug administration.

\section{Amphetamine induced pyrexia in mice}

The study was in accordance to Okokon et al protocol, with little modification. ${ }^{21}$ The initial temperatures of rats recruited for this study were taken. The animals were grouped and each rat was administered with $5 \mathrm{mg} / \mathrm{g}$ of Damphetamine intraperitonealy to induce pyrexia. Twentyfour hours after, the rectal temperature of each rat was checked to confirm increase in temperature and animals showing increase in temperature of less than $0.6^{\circ} \mathrm{C}$ were not recruited for the study. Thereafter, animas were treated with graded doses of the root extract $(50 \mathrm{mg} / \mathrm{kg}, 100 \mathrm{mg} / \mathrm{kg}$ and $200 \mathrm{mg} / \mathrm{kg}$ ) were administered orally to three groups of wistar rat, while distilled water $(20 \mathrm{ml} / \mathrm{kg})$ and $150 \mathrm{mg} / \mathrm{kg}$ of paracetamol were administered to the remaining two groups (drug free and standard drug). The rectal temperature of each rat was then observed at interval of 1 hour for 5 hours.

\section{Statistical analysis}

Results are presented as mean \pm standard error of mean (SEM) and analyzed with statistical package for social sciences (SPSS version 20) using one-way analysis of variance (ANOVA) followed by Dunnett's post hoc test. Difference in the mean $\mathrm{p}<0.05)$ was statistically considered significant.

\section{RESULTS}

\section{Phytochemical analysis}

The phytochemical screening of S. lehmbschii ethanol root extract revealed the presence of alkaloids, saponins, tannins, flavonoids, terpenoids, steroids, cardiac glycosides, resins and balsam as reported by Akuodor et $\mathrm{al}^{22}$

\section{Acute toxicity studies}

There was no observed changes, mortality or signs of toxicity 72 hours after administration of the ethanol root extract. The animals were all healthy and active throughout the study. Hence, the median lethal dose $\left(\mathrm{LD}_{50}\right)$ was found to be greater than $5000 \mathrm{mg} / \mathrm{kg}$.

\section{Anti-nociceptive studies}

The root extract of S. lehmbachii significantly and dose dependently decreased the number of acetic-acid induced writhes at $p<0.05$ and $p<0.01$. The observed effects of the extract at $200 \mathrm{mg} / \mathrm{kg}$ was higher than that of $50 \mathrm{mg} / \mathrm{kg}$ and $100 \mathrm{mg} / \mathrm{kg}$. This effect was comparable to that of the standard drug (Table 1).

Table 1: Effect of ethanol extract of S. lehmbachii root bark on acetic acid-induced writhing in mice.

\begin{tabular}{|llll|}
\hline Treatment & $\begin{array}{l}\text { Dose } \\
(\mathrm{mg} / \mathrm{kg})\end{array}$ & $\begin{array}{l}\text { Mean no. } \\
\text { of writhes }\end{array}$ & $\begin{array}{l}\text { Inhibiti- } \\
\text { on }(\%)\end{array}$ \\
\hline Distilled water & $20 \mathrm{ml} / \mathrm{kg}$ & $23.33 \pm 4.93$ & - \\
\hline \multirow{3}{*}{ S. lehmbachii } & 50 & $9.00 \pm 1.38$ & $61^{\mathrm{a}}$ \\
\cline { 2 - 4 } & 100 & $5.33 \pm 1.11$ & $77^{\mathrm{a}}$ \\
\cline { 2 - 4 } Aspirin & 200 & $3.50 \pm 0.72$ & $85^{\mathrm{b}}$ \\
\hline
\end{tabular}

Results are mean \pm SEM; $(\mathrm{n}=6),{ }^{\mathrm{a}} \mathrm{P}<0.05,{ }^{\mathrm{b}} \mathrm{P}<0.01$ compared to control. 
Table 2: Effect of ethanol extract of $S$. lehmbachii root bark on tail immersion in mice time interval (min).

\begin{tabular}{|c|c|c|c|c|c|c|}
\hline & & Pre-treatment & After-treat & & & \\
\hline Treatment & Dose mg/kg & $\mathbf{0}$ & 30 & 60 & 90 & 120 \\
\hline \multirow{3}{*}{$\begin{array}{l}\text { S. } \\
\text { lehmbachii }\end{array}$} & 50 & $6.50 \pm 0.43$ & $8.50 \pm 0.50$ & $10.83 \pm 0.83$ & $11.67 \pm 0.71$ & $13.17 \pm 0.60^{\mathrm{a}}$ \\
\hline & 100 & $7.50 \pm 0.76$ & $9.33 \pm 0.76$ & $11.83 \pm 0.70$ & $13.50 \pm 0.56$ & $15.00 \pm 0.68^{\mathrm{a}}$ \\
\hline & 200 & $8.00 \pm 0.52$ & $10.17 \pm 0.79$ & $12.50 \pm 0.88$ & $14.67 \pm 0.56$ & $17.50 \pm 0.34^{\mathrm{b}}$ \\
\hline Morphine & 10 & $7.50 \pm 0.62$ & $17.50 \pm 0.72$ & $19.17 \pm 0.60$ & $21.17 \pm 0.87$ & $23.33 \pm 0.95^{\mathrm{b}}$ \\
\hline
\end{tabular}

Results are mean \pm SEM; $(\mathrm{n}=6){ }^{\mathrm{a}} \mathrm{P}<0.05,{ }^{\mathrm{b}} \mathrm{P}<0.01$ compared to control

Table 3: Effect of ethanol extract of S. lehmbachii root bark on carrageenan induced paw oedema in rats.

\begin{tabular}{|c|c|c|c|c|c|c|c|c|}
\hline \multicolumn{9}{|c|}{ Paw oedema (hours) } \\
\hline Treatment & Dose (mg/kg) & $\mathbf{0}$ & 0.5 & 1 & 2 & 3 & 4 & 5 \\
\hline $\begin{array}{l}\text { Distilled } \\
\text { water }\end{array}$ & $20 \mathrm{ml} / \mathrm{kg}$ & $1.24 \pm 0.02$ & $1.64 \pm 0.01$ & $1.72 \pm 0.02$ & $1.79 \pm 0.02$ & $1.86 \pm 0.02$ & $1.93 \pm 0.0$ & $2.01 \pm 0.02$ \\
\hline \multirow{3}{*}{$\begin{array}{l}\text { S. } \\
\text { lehmbachii }\end{array}$} & 50 & $1.22 \pm 0.03$ & $1.60 \pm 0.02$ & $1.53 \pm 0.03$ & $1.46 \pm 0.02$ & $1.38 \pm 0.03$ & $1.31 \pm 0.02 *$ & $1.20 \pm 0.02^{\mathrm{a}}$ \\
\hline & 100 & $1.24 \pm 0.02$ & $1.63 \pm 0.01$ & $1.56 \pm 0.02$ & $1.48 \pm 0.02$ & $1.30 \pm 0.03$ & $1.24 \pm 0.02$ & $1.18 \pm 0.02^{\mathrm{a}}$ \\
\hline & 200 & $1.18 \pm 0.03$ & $1.57 \pm 0.03$ & $1.49 \pm 0.03$ & $1.38 \pm 0.02$ & $1.30 \pm 0.04$ & $1.21 \pm 0.03$ & $1.15 \pm 0.03^{b}$ \\
\hline Aspirin & 150 & $1.17 \pm 0.04$ & $1.61 \pm 0.02$ & $1.49 \pm 0.02$ & $1.39 \pm 0.03$ & $1.30 \pm 0.03$ & $1.22 \pm 0.03$ & $1.12 \pm 0.03^{b}$ \\
\hline
\end{tabular}

*Results are mean \pm SEM; $(\mathrm{N}=6){ }^{\mathrm{a}} \mathrm{P}<0.05,{ }^{\mathrm{b}} \mathrm{P}<0.01$ compared to control

Table 4: Effect of ethanol extract of S. lehmbachii root bark on xylene-induced ear oedema in mice.

\begin{tabular}{|llllll|} 
Treatment & $\begin{array}{l}\text { Dose } \\
(\mathrm{mg} / \mathrm{kg})\end{array}$ & $\begin{array}{l}\text { Weight of ear } \\
\text { Right ear }\end{array}$ & Left ear & Increase in weight & Inhibition (\%) \\
\hline Distilled water & $20 \mathrm{ml} / \mathrm{kg}$ & $0.065 \pm 0.00$ & $0.300 \pm 0.00$ & $0.020 \pm 0.00$ & - \\
\hline \multirow{3}{*}{ S. lehmbachii } & 50 & $0.052 \pm 0.00$ & $0.030 \pm 0.00$ & $0.020 \pm 0.00$ & $51^{\mathrm{a}}$ \\
& 100 & $0.040 \pm 0.00$ & $0.028 \pm 0.00$ & $0.016 \pm 0.00$ & $63^{\mathrm{a}}$ \\
\hline Dexamethazone & 4 & $0.030 \pm 0.00$ & $0.018 \pm 0.00$ & $0.008 \pm 0.00$ & $83^{\mathrm{b}}$ \\
\hline
\end{tabular}

Results are mean $\pm \mathrm{SEM}$; $(\mathrm{N}=6){ }^{\mathrm{a}} \mathrm{P}<0.05,{ }^{\mathrm{b}} \mathrm{P}<0.01$ compared to control

The ethanol root extract of S. lehmbachii significantly at $\mathrm{p}<0.05$ and $\mathrm{p}<0.01)$ reduced the thermal stimuli in mice. In this test, dose dependent reduction was produced by the extract. However, morphine (reference drug), showed stronger protection (Table 2).

\section{Anti-inflammatory studies}

The anti-inflammatory activity of S. lehmbachii ethanol root extract was observed to be dose dependent. There was significant activity at $\mathrm{p}<0.05$ with $50 \mathrm{mg} / \mathrm{kg}$ and 100 $\mathrm{mg} / \mathrm{kg}$ doses of the extract, whereas the highest dose of the extract $(200 \mathrm{mg} / \mathrm{kg})$ had $\mathrm{p}<0.01$ significant activity. The reference drug (ASA) had more activity in this study (Table 3). The anti-inflammatory activity began at 1 hour after administration of drug and lasted for 5 hours before completely vanishing.

The anti-inflammatory effect of S. lehmbachii ethanol root extract against xylene induced ear oedema in mice is shown in Table 4. The extract exhibited significant and dose dependent activity reduction of oedema at $\mathrm{p}<0.05$ and $\mathrm{p}<0.01$ with the highest dose of the extract comparable to the standard drug, dexamethasone.

\section{Antipyretic studies}

Table 5 shows the antipyretic effect of the ethanol root extract of S. lehmbachii determined using Brewer's yeast induced pyrexia in rats. The extract exerted significant and dose dependent antipyretic action at $p<0.05$, whereas the standard drug showed significant antipyretic activity at $\mathrm{p}<0.01$.

The results of the effect of ethanol root bark extract of S. lehmbachii against D-amphetamine induced pyrexia is shown in Table 6 . There was a progressive dose dependent reduction at $p<0.05$ in the temperature of rats treated with the ethanol extract. The effect of the extract was less than the standard drug, acetylsalicylic acid (ASA). 
Table 5: Effect of ethanol extract of $S$. eahmbachii root bark against yeast induced pyrexia in rats (hours).

\begin{tabular}{|clllllll|}
\hline $\begin{array}{c}\text { Treat } \\
\text {-ment Dose } \\
\text { (mg/kg) }\end{array}$ & $\mathbf{0}$ & $\mathbf{2 4}$ & $\mathbf{1}$ & $\mathbf{2}$ & $\mathbf{3}$ & $\mathbf{4}$ & $\mathbf{5}$ \\
\hline $\begin{array}{c}\text { Distilled water } \\
20\end{array}$ & $35.37 \pm 0.05$ & $37.52 \pm 0.04$ & $37.80 \pm 0.02$ & $37.63 \pm 0.02$ & $37.42 \pm 0.02$ & $37.29 \pm 0.02$ & $37.30 \pm 0.03$ \\
\hline $\begin{array}{c}\mathrm{ml} / \mathrm{kg} \\
\text { S. lehmbachii }\end{array}$ & & & & & & & \\
\hline 50 & $35.26 \pm 0.03$ & $37.25 \pm 0.03$ & $36.41 \pm 0.01$ & $36.20 \pm 0.02$ & $35.62 \pm 0.03$ & $35.37 \pm 0.03$ & $35.24 \pm 0.02^{\mathrm{a}}$ \\
\hline 100 & $35.25 \pm 0.02$ & $37.27 \pm 0.02$ & $36.50 \pm 0.03$ & $36.22 \pm 0.01$ & $35.61 \pm 0.02$ & $35.36 \pm 0.03$ & $35.22 \pm 0.03^{\mathrm{a}}$ \\
\hline 200 & $35.23 \pm 0.02$ & $37.30 \pm 0.02$ & $36.47 \pm 0.02$ & $36.15 \pm 0.01$ & $35.55 \pm 0.03$ & $35.30 \pm 0.02$ & $35.10 \pm 0.03^{\mathrm{a}}$ \\
\hline Aspirin & & & & & & & \\
\hline 150 & $35.22 \pm 0.00$ & $36.79 \pm 0.02$ & $35.69 \pm 0.04$ & $35.43 \pm 0.02$ & $35.40 \pm 0.01$ & $34.60 \pm 0.02$ & $34.30 \pm 0.03^{\mathrm{b}}$ \\
\hline
\end{tabular}

Results are mean $\pm \mathrm{SEM} ;(\mathrm{N}=6){ }^{\mathrm{a}} \mathrm{P}<0.05,{ }^{\mathrm{b}} \mathrm{P}<0.01$ compared to control.

Table 6: Effect of ethanol root bark extract of S. lehmbachii on de-amphetamine induced pyrexia in rats (hours).

\begin{tabular}{|lllllllll|} 
Treatment & $\begin{array}{l}\text { Dose } \\
(\mathrm{mg} / \mathrm{kg})\end{array}$ & $\mathbf{0}$ & $\mathbf{2 4}$ & $\mathbf{1}$ & $\mathbf{2}$ & $\mathbf{3}$ & 4 & $\mathbf{5}$ \\
\hline $\begin{array}{l}\text { Distilled } \\
\text { water }\end{array}$ & $20 \mathrm{ml}$ & $35.25 \pm 0.04$ & $37.39 \pm 0.04$ & $37.61 \pm 0.04$ & $37.67 \pm 0.02$ & $37.46 \pm 0.05$ & $37.26 \pm 0.03$ & $37.70 \pm 0.03$ \\
\hline & 50 & $35.27 \pm 0.04$ & $37.29 \pm 0.02$ & $36.43 \pm 0.03$ & $36.23 \pm 0.03$ & $35.51 \pm 0.02$ & $35.30 \pm 0.02$ & $35.25 \pm 0.02^{\mathrm{a}}$ \\
S. lehmbachii & 100 & $35.20 \pm 0.03$ & $37.30 \pm 0.02$ & $36.40 \pm 0.02$ & $36.23 \pm 0.02$ & $35.52 \pm 0.02$ & $35.31 \pm 0.02$ & $35.23 \pm 0.03^{\mathrm{a}}$ \\
& 200 & $35.24 \pm 0.02$ & $37.30 \pm 0.02$ & $36.33 \pm 0.02$ & $36.20 \pm 0.03$ & $35.48 \pm 0.02$ & $35.26 \pm 0.02$ & $35.21 \pm 0.01^{\mathrm{a}}$ \\
\hline Paracetamol & 150 & $35.25 \pm 0.03$ & $37.31 \pm 0.02$ & $36.39 \pm 0.03$ & $36.22 \pm 0.03$ & $35.49 \pm 0.01$ & $35.31 \pm 0.01$ & $34.17 \pm 0.01^{\mathrm{a}}$ \\
\hline
\end{tabular}

Results are mean \pm SEM; $(\mathrm{N}=6){ }^{\mathrm{a}} \mathrm{P}<0.05,{ }^{\mathrm{b}} \mathrm{P}<0.01$ compared to control

\section{DISCUSSION}

This study was carried out to establish the potential pharmacological properties of ethanol extract of $S$. lehmbachii based on claims of its use in herbal medicine. The findings of the present study reveal that $S$. lehmbachii (ethanol extract) at doses employed exhibited anti-nociceptive effects against chemical pains (writhing) induced by acetic acid. ${ }^{23}$ This chemical is popular for evaluating anti-nociceptive properties of plant extracts and drugs. ${ }^{24}$ Another report revealed that the response of mice to acetic acid is a fast and trusted method to test peripheral anti-nociceptive effect of herbal drugs. ${ }^{25}$

In the present work, the extracts of S. lehmbachii and acetylsalicylic acid (aspirin) inhibited acetic acid induced writhing. The results shows the extract has peripheral antinociceptive properties which suggest the action may be directed via inhibition of local peritoneal receptors. ${ }^{26}$ However, irrespective of whether the model evaluates peripheral anti-nociceptive action only or non-specific, the results validates the usefulness of this plant as an analgesic in Nigeria. The injection of acetic acid is reported to induce the release of mediators of pain such as prostaglandins and other cyclokinase. ${ }^{27,28}$ This suggests that the extracts of S. lehmbachii acted by inhibiting the actions of cycloxygenase which is said to be responsible for producing prostaglandins from arachidonic acids. ${ }^{28}$ The analgesic effects produced by the extract of the test plant (S. lehmbachii root bark) validate their use in traditional medical practice as analgesics.
In order to confirm the analgesic activity of the extract, centrally acting model of analgesia (tail immersion) was carried out. This method of analgesic assay which is used to indicate the involvement of central analgesic mechanism is believed to involve spinal reflex. ${ }^{29}$ It has been reported that centrally acting agents such as morphine, possess this activity in both types of study, whereas peripherally acting agents lie acetylsalicylic acid have been reported to exert anti-nociceptive action only in the writhing test. $^{30}$ Most importantly, the action of acetylsalicylic acid in writhing assay only could be linked with its ability to directly inhibit prostaglandin activity or indirectly inhibit prostaglandin secretion by inhibition of cyclo-oxygenase activity. ${ }^{31}$ The importance activity in tail immersion test shows involvement of central analgesic mechanism.

Carrageenan induced paw oedema is a suitable way of testing anti-inflammatory agents and this has widely been used for screening anti-oedematous action of natural products. $^{32}$ This process of testing acute inflammation potency is a highly sensitive tool. ${ }^{33}$ The development of oedema depend on the presence of bradykinin and polymorphonuclear leucocytes with proinflammatory factor such as prostaglandins. ${ }^{34}$ The root extract of S. lehmbachii may not have activity on the early phase of inflammation, hence may act by inhibiting the release of prostaglandins. Nonsteroidal anti-inflammatory agents like aspirin, may not inhibit the initial phase of edema induced by carrageenan whereas the second accelerating phase can be antagonized by the drug. ${ }^{35}$ 
Xylene causes irritation in mouse ear leading to accumulation of fluid and oedema and increase in myeloperoxidase enzymatic activity. ${ }^{36}$ Suppression of this response may suggest antiphlogistic activity. ${ }^{29}$ The ethanol extract of $S$. lehmbachii root exerted significant inhibition of ear oedema in mice. This activity suggests the inhibition of phospholipase $A_{2}$ which is involved in the pathophysiology of inflammation due to xylene. ${ }^{37}$ However, dexamethasone used as the reference drug exhibited significant decrease in the ear weight of positive control rats which indicate an inhibition of PLA 2 .

Antipyretic agents have been shown to antagonize cyclooxygenase activity via increase in prostaglandin $E_{2}$ thereby suppressing high temperature. ${ }^{38}$ Rise in temperature may be caused by damaged tissue, infections, and other diseases. This process will give rise to mediators (interleukins etc.), which progresses to prostaglandin $\mathrm{E}_{2}$ formation with increase body temperature. ${ }^{39}$ The extracts reduced rats' anal temperature. The observed effect was similar to that of aspirin. The ethanol root extract of S. lehmbachii could bring fever to a control by getting rid of inflammatory symptoms at both peripheral and nervous system thermoregulator zones. They could bring down pyrogenic secreting cytokines while reducing prostaglandin $\mathrm{E}_{2}$ synthesis from cyclooxygenase probably through the mechanism reputed for paracetamol. ${ }^{40}$

The therapeutic potentials of medicinal plants are mostly attributed to the combination of secondary metabolites. Flavonoids have been reported to target prostaglandins involved in late phase of acute inflammation and pain and they have therefore been associated with anti-nociceptive, anti-inflammatory and antipyretic activities. ${ }^{41-43}$ Therefore, it is not surprising to have seen these activities in the root extract. The $\mathrm{LD}_{50}$ result obtained showed the relative safety of the herbal agent as no death was recoded.

\section{CONCLUSION}

The results of present study show that the ethanol root of S. lehmbachii possess anti-nociceptive, anti-inflammatory and antipyretic activities, thus confirming the folklore uses of the plant for the treatment of different diseases.

\section{ACKNOWLEDGEMENTS}

Authors are grateful to Mr. Marcus Inyang and Etim Ifang for their technical assistance.

Funding: No funding sources Conflict of interest: None declared

Ethical approval: The study was approved by the Institutional Ethics Committee

\section{REFERENCES}

1. Chaudhari MG, Joshi BB, Mistry KN. In vitro antidiabetic and anti-inflammatory activity of stem bark of
Bauhinia purpurea. Bull Pharm Med Sci. 2013;1(2):139-50.

2. Zulfiker AHM, Rahman MM, Hossain MK, Hamid K, Mazumder MEH, Rana MS. In vivo analgesic activity of ethanolic extracts of two medicinal plantsScoparia dulcis L. and Ficus racemosa Linn. Biol Med. 2010;2(2):42-8.

3. Bellik Y, Boukraa L, Alzahrani HA, Bakhotmah BA, Abdellah F, Hammoudi SM, et al. Molecular mechanism underlying anti-inflammatory and antiallergic activities of phytochemicals: An update. Molecules. 2012;18:322-53.

4. Dalal S, Zhukovsky DS. Pathophysiology and management of fever. J Support Oncol. 2006;4:9-16.

5. Tirumalasetty J, Ubedulla S, Chandrasekhar N, Kishan PV, Rasamal K. Evaluation of antipyretic activity of alcoholic extract of Vitex nigundo leaves in PGE1 induced pyrexia model in Albino Rats. J Chem Pharm Res. 2012;4(6):3015-19.

6. Essien AD, Akuodor GC, Essien EA, Asika EC, Chilaka KC, Nwadum SK. Evaluation of antipyretic potential of the ethanolic leaf extract of Salacia lehmbachii Loes. Asian J Med Sci. 2015;7(2):22-5.

7. Essien AD, Takem LP, Anele EI. In vitro cholinergic and acute toxicity evaluations of Salacia lehmbachii. Int J Pharm Pharm Res. 2016;5(1):200-7.

8. Takem LP, Lawal BAS, Udia PM. Analgesic and acute anti-inflammatory activities of aqueous root extract of Salacia lehmbachii. $\mathrm{Br} \mathrm{J}$ Pharm Res. 2014;4(18):2172-81.

9. Essiet GA, Essien AD, Udoh FV, Essiet A. Antifertility effects of ethanol extract of Salacia lehmbachii root bark in albino rats. J Adv Med Pharm Sci. 2016;8(4):1-8.

10. Sofowora A. Medicinal Plants and Traditional Medicine in Africa. Ibadan: Spectrum Books; 1993: 200.

11. Akuodor GC, Essiet GA, Essien AD, Udoh FV, Ogiji DE, Nwadum SK, et al. In vitro antioxidant activity of Salacia lehmbachii ethanol root bark extract. Eur $\mathbf{J}$ Med Plants. 2017;18(4):1-6.

12. National Institutes of Health. Guide for the Care and Use of Laboratory Animals. 8th ed. Bethesda, MD: NIH; 2011. 82-3.

13. OECD. OECD Guideline for Testing of Chemicals (TG 401). Acute Oral Toxicity- Fixed Dose Procedure. 2011.

14. Koster R, Anderson M, Beer EJ. Acetic acid analgesic screening. Federation Proc. 1959;18: 412-7.

15. Akuodor GC, Anyalewechi NA, Udoh FV, Ikoro NC, Akpan JL, Gwotmut MD, Pharmacological evaluation of Verbena hastate leaf extract in the relief of fever. Adv Pharmaco Toxico 2011;12(3):1-8.

16. Kalpesh G, Nema RK, Kori ML, Sharma CS, Singh V. Anti-inflammatory and analgesic activity of Balanites aegyptiaca in experimental animal models. Int $\mathbf{J}$ Gastroenterol. 2008;214-7.

17. Winter CA, Risley EA, Nuss GW. Carrageenininduced edema in hind paws of the rat as an assay for 
anti-inflammatory drugs. Proc Soc Exp Med. 1962;111:544-7.

18. Oyewole IO, Ibidapo CA, Moronkola DO, Oduola AO, Adeoye GO, Anyasor GN, et al. Antimalarial and repellent activities of TIthonia diversifolia (Hemsl.) leaf extracts. J Med Plants Res. 2008;2(8):171-5.

19. Agbaje EO, Ajidahun OA. Analgesic, Antiinflammatory and antipyretic effect of dried root ethanolic extract of Strophantus sarmentosus (apocynaceae). Int Res J Pharm Pharmacol. 2011;629.

20. Hassan FI, Abdulkadir UZ, Yaro AH, Danmalam UH. Analgesic, anti-inflammatory and antipyretic activities of themethanol leaf extract of Dalbergia saxatilis Hook. in rats and mice. J Ethnopharmacology.2015;166:74-8.

21. Akuodor GC, Essiet GA, Ekenjoku JA, Udoh FV, Ogiji ED, Ibiam GA, et al. Antidiarrhoael and antimicrobial effects of ethanol root bark extract from Salacia lehmbachii. J Herbmed Pharmacol.2021;10(2):188-93.

22. Okokon JE, Nwafor PA. Anti-inflammatory, analgesic and antipyretic activities of ethanolic root extract of Croton zambesicus. Pak J Pharm Sci. 2010;23(4):38592.

23. Shaa KK, Oguche S, Watila IM, Ikpa TF. In vitro antimalarial activity of the extracts of Vernonia amygdalina commonly used in traditional medicine in Nigeria. Science World J. 2011;6(2):5-9.

24. Du J, Yu Y, Ke Y, Wang C, Qian ZM. Ligustilide attenuates pain behavior induced by acetic acid or formalin. J Ethnopharmacology. 2007;112:211-4.

25. Essien AD, Edidara Thomas, Essiet GA, Akuodor GC. Anti-inflammatory, antipyretic and anti-nociceptive activities of the ethanol stem bark extract of Salacia lehmbachii. British Pharmacol Toxicol. 2017; 8(2):916.

26. Mbiantcha M, Kamanyi A, Teponno RB, Tapondjou AL, Watcho P, Nguelefack T. Analgesic and AntiInflammatory Properties of Extracts from the Bulbils of Dioscorea bulbifera L. var Sativa (Dioscoreaceae) in Mice and Rats. Evid Based Compl Altern Med. 2011:912935.

27. Divya TS, Latha PG, Usha K, Anuja GI, Suja SR, Shyamal S, et al. Anti-inflammatory, analgesic and anti-lipid peroxidative properties of Wattakaka volubilis (Linn). Natur Prod Rad. 2009;8(2):137-41.

28. Nkeh CNB, Bekwa PCM, Ndebia JE, Kayo M, Mbafor TJ, Iputo EJ. Analgesic and anti-inflammatory properties of Oxyanthus unilocularis. J Med Plants. 2010;4(10):932-9.

29. Akuodor GC, Essien AD, Udia PM, David-Oku E, Chilaka KC, Asika EC, Nwadum SK. Analgesic, Antiinflammatory and Antipyretic potential of the stem Bark Extract of Stachytarpheta indica. British J Pharmacol Toxicol. 2015;6(1):16-21.

30. Ezeja M, Ezeigbo I, Madubuike KG. Analgesic activity of the methanolic seed extract of Buchholzia coriacea. Res J Pharm Biol Chem Sci. 2011;2(1):18793.

31. Kumar A, Agarwal K, Kumar MA, Shanker K, Bushra $\mathrm{U}$, Tandon S, et al. Pharmacological and phytochemical evaluation of Ocimum sanctum root extract for its anti-inflammatory, analgesic and antipyretic activities. Pharmacognosy Mag. 2015;11(42):217-24.

32. Panthong A, Kanjanapothi D, Taesotikul T, Wongcome T, Reutrakul V. Anti-inflammatory and antipyretic properties of Clerodendrum petasites. J Ethnopharmacology. 2003;58:151-6.

33. Xu Z, Zhou J, Cai J, Zhu Z, Sun X, Jiang C. Antiinflammation effects of hydrogen saline in LPS activated macrophages and carrageenan induced paw oedema. Inflammation. 2012;9:2

34. Necas J, Bartosikova L. Carrageenan: A review. Veterinary Med. 2013;58:187-205.

35. David OE, Akuodor GC, Edet EE, Ogbuji GK, Obiajunwa OJI, Aja DOJ. Antinociceptive, antiinflammatory and antipyretic effects of ethanolic root bark extract of Icacina senegalensis in rodents. J Appl Pharmaceut Sci. 2016;6(02):104-3.

36. Yazmin RC, Vivian MC, Yohani PG, Ambar OY, Sonia JD, Rosa MF. Anti-Oedema Effects of D-002 and Lyprinol on the Carrageenan-Induced Pleurisy in Rats. Int J Pharm Sci Rev Res. 2013;23(1):24-8.

37. Megwas1 AU, Akuodor GC, Chukwu LC, Aja DO, Okorie EM, Ogbuagu EC, et al. Analgesic, antiinflammatory and antipyretic activities of ethanol extract of Annona senegalensi leaves in experimental animal models. Int $\mathbf{J}$ Basic Clin Pharmacol. 2020;9(10):1477-84.

38. David M, Aronoff MD, Eric G, Neilson MD. Antipyretics: mechanisms of action and clinical use in fever suppression. Amer J Med. 2001;111(4):304-15.

39. Boron WF, Boulpaep EL. Medical Physiology: A Cellular and Molecular Approach. 2nd ed. Philadelphia, PA : Saunders/Elsevier, 2009; 1300.

40. Sumanta M, Gouri KD, Suman A. Analgesic, antiinflammatoty and antipyretic studies of Neolamarckia cadamba barks. J Pharma Res. 2009;1:1133-6.

41. Agoreyo BO, Okoro NC, Choudhary MI. Preliminary phytochemical analysis of two varieties of Adenia lobate and the antioxidant activity their various solvent fractions. Bayero J Pure and Appl Sci. 2012;5(1):182-6.

42. Savithramma M, Rao ML, Suhrulatha D. Screening of medicinal Plants for secondary metabolites. MiddleEast J Scient Res. 2011;8(3):579-84.

43. Nassar N, Abeywardana P, Barker A, Bower C. Parental occupational exposure to potential endocrine disrupting chemicals and risk of hypospadias in infants. Occupational. Environment Medicine. 2010;67:585-9

Cite this article as: Akuodor GC, Ohadoma SC, Ofor CC, Megwas AU, Chukwu LC, Ramalan MA,, et al. Anti-nociceptive, anti-inflammatory and antipyretic activities of the ethanol root bark extract of Salacia lehmbachii in rats and mice. Int J Basic Clin Pharmacol 2021;10:614-20. 